\title{
Effectiveness and Efficiency of Solid Waste Services in Lagos State, Nigeria
}

\author{
Ayadi, F. S. ${ }^{1, *}$ and Alo, B. I. ${ }^{2}$ \\ ${ }^{1}$ Department of Economics, Faculty of Social Sciences, University of Lagos, Akoka-Yaba, Lagos State, Nigeria \\ ${ }^{2}$ Department of Chemistry, Faculty of Sciences, University of Lagos, Akoka-Yaba, Lagos State, Nigeria \\ Corresponding Author: *funso123@yahoo.com
}

https://doi.org/10.36263/nijest.2020.02.0214

\begin{abstract}
Lagos is the largest producer of municipal solid waste in Nigeria, yet it is the smallest of Nigeria's 36 states with the highest projected population, highest level of urbanization and it houses Nigeria's largest chief port, and principal economic and cultural centres. Out of the total waste generated, only about 73 percent actually got to the final disposal site. There is a possibility of inefficient and ineffective municipal solid waste management system in place which can damage the ecosystem services, contaminate ground and surface water, creates greenhouse gas emissions, increase disease transmission, damages ecosystem services and discourages tourism and other businesses. To this end, this study analysed the efficiency and effectiveness of solid waste services and; the efficiency and effectiveness of solid waste services in Lagos State using primary data and conducting statistical tests. The study found a general agreement on what constitutes efficient and effective solid waste services. However, the study concluded that the waste management system in Lagos State is inefficient, ineffective and therefore; unsustainable. The study therefore recommends among others the urgent need to re-organize the waste management institutions for effective and efficient performance. This requires substantial planning ability, appropriate equipment and continuous managerial optimization of vehicles and workers productivity, efficient vehicle routing, better designed vehicles, managerial incentives, faster vehicle repairs, vehicle standardization.
\end{abstract}

Keywords: Municipal solid wastes, Efficient and effective, Cart pushers, Environment, Landfills

\subsection{Introduction}

All Nigerian major cities like Abuja, Benin, Enugu, Ibadan, Kano, Kaduna, Lagos and Port-Harcourt are desirous of cost-effective and ecosystem-sustaining regime of municipal solid waste management because households in these States generate about a tonne of municipal waste annually and the trend is expected to skew upward in the future due to urbanization trends (Adeogba, 2000).

Lagos is the largest producer of municipal solid waste in Nigeria as it generates an average of 7,500 metric tonnes minimum per day, yet it is the smallest of Nigeria's 36 states with an area of 3,345 square kilometres (1292 sq. miles) which represents about 0.36 percent of Nigeria's land mass of 923,768 sq. kilometres but with a population of 5,725,116 which was 6.4 percent of Nigeria's population as at 1991. The population was projected to rise to 7,877,810 by the year 2002 (Nigerian State and Local Government Area Demographic Profile 1999-2010). It has a population density of 1712 per square kilometre based on the population census of 1991 (Population Census of the Federal Republic of Nigeria Analytical Report at the National level NPC 1991). This density figure was estimated to be 2,355 persons per square kilometre by 2002 (computed by the author based on the projected 2002 population). Lagos has about 17 percent water bodies and over 41 blighted/slum settlements- a fall out of premature and spontaneous Urbanization. It has a flat topography, a high water table, endemic perennial flooding and it is swampy (Adeogba, 2000). All these combined constrains waste management.

Moreover, despite the increases in income, pollution and waste management problems have assumed a predictable upward trend in conformity with the antigrowth theorists in a dynamic World where the 
pro-growth view holds sway. Waste generation is on the increase and the average waste generation per capita a day in the city is $0.55 \mathrm{~kg}$ while the least waste generated per day in the state is 7,500 metric tonnes. Out of the total waste generated, only about 73 percent actually got to the final disposal site (Lagos State Waste Management Authority (LAWMA) gate records).

The above situation portrays the ineffective and inefficiency of waste management institutions which has the potential of adversely affecting the economic and social life apart from posing risks to the health of the people of Lagos state since the visual quality of an urban environment contributes to the residents' self-identification with their neighbourhood. It also determines the potential of the particular area for fleas, home out-door oriented recreation and thus contributes significantly to the well-being of the citizens. In the same vein, a pleasant appearance of a city attracts private investors and revenue generating enterprises and, therefore, promotes economic well-being of a neighbourhood. An unpleasant appearance on the other hand as it is in Lagos presently contributes to the exact opposite effects i.e. Withdrawal of higher income investors, public negligence and accelerated deterioration of physical, economic and social living conditions (Adeogba, 2000).

In a nutshell, the role of the Lagos State Waste Management Authority(LAWMA) in solid waste management in Lagos State can be summarized under: Collection and disposal of industrial and commercial waste; complementary service to Highway Managers Limited, in removing the abandoned wastes in streets, markets, roads and so on. The Local Government Councils that also has the primary duty of wastes collection; and Private Sector Participants (PSP) that were licensed to collect domestic waste, management landfill sites and waste Transfer Loading Stations (TLS). According to Adedayo (2000), the solid waste management system outlines the processes involved in the management of solid waste from the source of generation down to the disposal site. Theoretically, the following stages are recognized: generation, storage, collection, transportation/transfer, treatment/recycling and disposal.

In actual practice, most especially in developing countries especially in Nigerian cities, we have the following stream of waste: generation, separation of re-usable by sweepers, storage at waste bins, collection, transportation, scavenging by vehicle crews/drivers, disposal/Sales of recovered items, scavenging and reuse at dump site by resident scavengers. Since the objective of an efficient waste management system is to collect, transport, treat, and dispose wastes in a hygienic, aesthetically pleasing and environmentally acceptable manner at the lowest cost possible, it is important to look at the waste management problem facing LAWMA as evidenced by its waste collection activities.

The three main methods of waste collection in Nigeria are: house-to-house collection, collection from centralized points or communal depots and collection from kerbsides. House-to-house collection is practiced in residential areas and other well-planned areas of Lagos City especially in high income low density residential areas, waste bins and bags are usually provided by the government or the private sector participants (PSP) who would have signed agreement with each household as per the cost as well as the suitable time of collection. In this arrangement, collection crew enters each premise to collect the refuse on regular basis. Collection from centralized points or communal depots involved placing communal waste storage facilities mainly by the side of the road or other areas with vehicular access and high population density and households just discharge their wastes into the depots where refuse collection vehicles visit these sites at frequent interval to collect these communal wastes. Collection at kerbsides is popular where depots are not in use or non-existent but waste generation is high. Roadsides and open spaces are usually used for depositing bins and bags for refuse from where they are emptied.

A safe disposal of solid waste is a must in effective waste management, the existing methods in use in Lagos State depicts some defects as residents discharge off their refuse in unauthorized places, open spaces, gutters and streams. Others burn their refuse openly while some dump in open dumpsites. Dumpsites are usually disused pits, valley or ditch where wastes are dumped without treatment, grading or placement of a layer of inert materials to prevent the breeding of flies, mosquitoes and disease carrying vectors. Lagos has 32 approved dumpsites as observed by the UDBN Survey (1997).

Presently, there are no sanitary landfills in Lagos state, but there are three major dumpsites in Lagos State with average depth of 18 metres each and sizes of 42.0, 10.5 and 9.3 hectares respectively. 
Incineration is another disposal method which involves waste processing technique by which solid, liquid and gaseous combustible matter if converted to a residue and to gasses by refuse burning and the residue in form of ashes is left as an end product. The main incineration plant in Lagos State was the Oshodi Incineration Plant which has been converted to a transfer station because of the releases of obnoxious gases such as carbon-monoxide, nitrogen oxides, acid gases, etc. as end-products as against the modern incinerators which are safer with by-products used as a source of energy. Other method of disposal is the composting which is a biological decomposition of wastes of organic origin under controlled circumstances to a condition sufficiently stable for nuisance-free storage and for use in agriculture.

In Lagos State, waste management is regarded as a municipal function and as such is expected to be borne by the Local Governments. The bulk of their revenues come from state subvention, Local Government deductions, other source of finance is through property tax, which is based on the value of the property. This is usually revalued every 5 years. A percentage of the property value is determined $\left(2 \frac{1}{2} \%\right.$ to $\left.10 \%\right)$ as property tax, from which a determined percentage is passed on for waste management. With the commercialization of waste services, the state government Board responsible for waste management is LAWMA. The board derives funding from internally generated revenue from industrial waste collection (user charges). As at mid-2001, a total of about 260 industrial premises were serviced by LAWMA and revenue accruing from such is put at an average of $\$ 10$ million per month. In December 1999, the PSP programme was set up in a bid to effectively manage the large volume of municipal waste generated daily in the state (LAWMA, 2011). The PSPs were employed to manage the domestic waste by charging households an agreed user's fee so as to enjoy the services of the PSPs and they are under the Local Government of their operation.

According to World Bank's World Development Report, 1991, public spending in developing countries are comparably high for the level of development they have attained. For instance, total expenditure is about 20 percent of GNP in low-income countries while it is about 30 percent of GNP for their middle-income counterparts. The import of the above is the need for a smaller and more efficient public sectors and or a more dynamic private sector in order to utilize resources more efficiently (Coyaud, 1988). To this end therefore, this study will explore the factors determining the efficiency and effectiveness of solid waste services generally and; also investigate the level of efficiency and effectiveness of the providers of solid wastes services in Lagos State and then offer useful suggestions based on findings.

\subsection{Literature Review}

Kütting (2001) defines environmental effectiveness as the extent to which degradation or polluting processes and consequences are curtailed or reversed as a result of action taken. Boateng et al. (2016) stated that to make waste management efficient, local governments and other wastes service providers should have reliable and sustainable means of collecting funds to cover the costs of services. Kütting (2000) classified effectiveness into two major categories which are the Norwegian school and the American school. The Norwegian school according to Kütting (2000) rather than suggesting an explicit definition for the subject matter obtained indicators that evaluates under which conditions a cooperative arrangement will be effective. The American school evaluates effectiveness by concentrating on institutional workings which is common among theorists. Kütting (2000) succinctly put it and define effectiveness as the ability of a procedure to solve a particular problem.

According to Adedibu (1985) developing countries are similar in the management of solid wastes which are characterized by lack of sufficient public and private funds, corruption, lack of planning, poor or lack of wastes separation at source, and unscientific and informal waste disposal methods.

Fei-Baffoe et al. (2014) identified some factors that hinder effective solid waste management as including lack of waste management personnel, lack of appropriate technologies, and poor enforcement of laws. Fei-Baffoe et al. (2014) further identified the constraints of waste management as general lack of finance due to inability to pay private waste collector contractors which compel people to resort to sharp practices. Lack of access to adequate waste collection facilities has also fuelled indiscriminate dumping of solid waste according to Boadi and Kuitunem (2005). Barbereyie (2009) observed that some factors affect waste management such as improper planning, financial misappropriations and poor waste disposal equipment management especially in Ghana. 
Efficiency entails lowering of costs relative to the resultant benefits. Cointrean-Levine (1994) explained the effectiveness and efficiency of waste management in the following context: cost recovery, accountability, finance, economies of scale, efficiency, management, legislation, cost and; Institutional management.

According to Cointrean-Levine (1994) the local government of developing countries' expenditure incurred on municipal waste services is normally between 20 to 50 percent of total municipal expenditure. Even at that level of high expenditure, solid waste services is relatively low in comparison with expenditure committed (inefficiency) as about 50 to 70 percent of solid waste is collected. This therefore calls for the private sector participation (PSP) in waste management services. PSPs are believed to be more efficient than the public sector in providing the municipal waste services because their efficiency is derived from managerial flexibility, greater financial discipline, freedom of action and accountability to market forces Cointrean-Levine (1978-1992).

According to Das et al. (2008) lack of financial resources, weak institutional framework and improper technology choice and public apathy towards the municipal solid wastes are some of the hindrances to achieving efficient and effective solid wastes management. Inefficient and ineffective waste management portends great danger. According to Alan and Ahmade (2013) and Fenta (2017) inefficient municipal solid waste management system can damage the ecosystem services, contaminate ground and surface water, creates greenhouse gas emissions, increase disease transmission, damages ecosystem services and discourages tourism and other businesses.

Das et al. (2008) conducted a study with the intention of designing efficient and effective solid waste management services in two municipalities in greater Kolkata via experiment on 101 residents of stated preference choice to estimate residents' valuation of various solid waste management (SWM) services attributes such as frequency of waste collection, whether or not vats are covered and; whether or not waste is collected by covered trucks among others. Results showed significant conditional and unconditional heterogeneity in residents' preferences for improvements in solid wastes services.

Orhorhoro and Oghoghorie (2019) did intensive review on solid wastes generation and management using Nigeria as a case study. They observed that there is inefficiency in solid waste management by individuals, households, institutions, consumers and waste management companies due to inadequate information on benefits of waste management, financial constraints, economic constraints, cultural constraints, poor planning and projections, social constraints, poor policy implementation, lack of adequate legal framework, lack of producers' involvement in waste management among other findings.

Choi (2016) conducted a study into the environmental effectiveness of solid waste management in Oslo, Norway by looking at four determinants of environmental effectiveness which are: regulatory structure, economic structure, time and science. He found environmental effectiveness of waste management limited in Oslo.

Das et al. (2008) conducted a study with the intention of designing efficient and effective solid waste management services in two municipalities in Greater Kolkata via experiment on 101 residents of stated preference choice to estimate residents valuation of various solid waste management (SWM) service's attributes such as; frequency of waste collection, whether or not vats are covered and; whether or not waste is collected by covered trunks among others.

LAWMA (2011) waste management in Lagos state has been fraught with many problems. It is inefficient due to a number of factors which include but not limited to; funding problems and inadequate planning. Waste generation in the state is estimated at about 9,000 metric tonnes a day. Ojolowo and Wahab (2019) observed that the quantity of solid waste generated far surpass the quantity collected in Lagos metropolis from 2007 to 2013. 21,550,809.73 (representing 27.7\%) was collected out of 77,757,749.8 tons (100\%) generated while 56,206,940.07 (72.3\%) uncollected. The uncollected waste was dumped indiscriminately. In order to further improve the solid waste services in Lagos state, this study will look at the determinants of effective and efficient waste management identified in the literature above and explore to what extent waste providers have fared in their duties. 


\subsection{Methodology}

\subsection{Materials}

In trying to determine the factors that contribute to effective and efficient waste management in Lagos; and to also assess the level of efficiency and effectiveness of waste service providers in Lagos, the study administered some primary instruments

The questionnaires of the study were administered in a stratified random sampling process on the household sector. 1,000 questionnaires in all were given out, out of which 504 were returned. The stratified sampling technique was to give out 50 questionnaires each to the 20 former Lagos State council areas. The major problem with this sampling technique is that respondents could not be tracked down at home and as such, questionnaires were administered on respondents mainly at their working places and in this case, there was no assurance that the strata stipulations was strictly followed as many people are not residing even close to where they work. Categorization of our data based on those zones could not be accomplished because some respondents did not disclose their addresses. However, we feel that this sampling technique may not necessarily lead to high sampling error. The distributions of the 1000 questionnaires are hereunder given;

Total Household surveyed

Total PSP Patrons 194

Cart pushers' patron 220

Self-disposal 24

Did not state service providers 25

Badly completed questionnaires 41

Total questionnaires returned $\mathbf{5 0 4}$

The instruments used in the study have a part in which companies and households were expected to check in on five options in an eight-question matrix which seeks to find out their perception of what an efficient and effective waste management should entail. In other words, they tick one of the options and Likert scales were allocated on them as follows: I strongly agree (5 points), I agree (4 points) it depends ( 3 points) I disagree ( 2 points) and I strongly disagree ( 1 point). In addition, the other instrument indicated the ranking of each waste service provider as perceived by the households and firms based on the ranking criteria.

\subsection{Methods}

The major tool of analysis here was the difference of two means.In carrying out this test, we formulated a null hypothesis of no significance difference between the population means $(\mu)$ of respondents (cart pushers' customers and PSP customers) since the two groups are expected to belong the two strata of the society in terms of average education and income level (Ayadi, 2008). In other words:

$\mathrm{H}_{0}: \mu_{1}-\mu_{2}=0$

$\mathrm{H}_{\mathrm{A}}: \mu_{1}-\mu_{2}=0$

The $Z$ formula utilized for testing the difference of two means is:

$Z=\frac{\left(\bar{X}_{1}-\bar{X}_{2}\right)}{\sqrt{\frac{S_{1}^{2}}{n_{1}}+\frac{S_{2}^{2}}{n_{2}}}}$

Where:

$\bar{X}_{1}$ is the mean value of private sector participants' (PSPs) patron's responses

$\bar{X}_{2}$ is the mean value of the cartpushers' patrons' responses.

$S_{1}^{2}$ is the variance for the PSP patrons' sample

$S_{2}{ }^{2}$ is the variance for cartpushers' patrons' sample 
$n_{1}$ is the number of PSP patrons in the sample

$n_{2}$ is the number of cartpushers patrons sampled

Our test is a two-tailed test and we take $\propto$ (level of significance) to be 0.02 . The decision rule is: If $Z$ - calculated is greater than Z-critical at $\propto=0.02$, reject the null hypothesis and accept the alternative hypothesis that the average responses by PSP patrons is significantly different from those of the cartpushers' patron. If our result indicates the contrary, then we shall accept the null hypothesis.

\subsection{Results and Discussion}

The results below indicated the ranking of each waste service provider as perceived by the households and firms. The major tool of analysis here is the difference of two means. The difference of two means result for the incomes of PSP patrons and the cartpushers' patrons produced a $Z_{\text {calculated }}$ as indicated on the last column and the $Z_{\text {critical }}$ at $\alpha=0.02$ is; 2.33 .

Table 1: Residential clients' opinion of effective and efficient waste management

\begin{tabular}{|c|c|c|c|c|c|c|c|c|}
\hline $\mathrm{S} / \mathrm{N}$ & & $\begin{array}{l}\text { Score } \\
\text { custon }\end{array}$ & by & artpusher's & Scores by & P's custon & & Results \\
\hline \multirow[t]{2}{*}{1} & \multirow{2}{*}{$\begin{array}{l}\text { Commensurate service charges } \\
\text { with level of solid waste } \\
\text { disposal. In other words, waste } \\
\text { service delivery must not be } \\
\text { too costly. }\end{array}$} & $\begin{array}{l}\text { Obse } \\
\text { rvati } \\
\text { ons }\end{array}$ & $\begin{array}{l}\text { Mean } \\
\text { scores } \\
\text { Cartpush } \\
\text { ers } \\
\end{array}$ & $\begin{array}{l}\text { STD. } \\
\text { DEV. }\end{array}$ & $\begin{array}{l}\text { Number } \\
\text { of } \\
\text { Observati } \\
\text { ons }\end{array}$ & $\begin{array}{l}\text { Mean } \\
\text { scores } \\
\text { PSP cust }\end{array}$ & $\begin{array}{l}\text { STD } \\
\text { DEV }\end{array}$ & $\begin{array}{l}\text { Diff. of two } \\
\text { means } \\
Z_{\text {calculated }}\end{array}$ \\
\hline & & 174 & 4.32 & 0.76 & 220 & 4.21 & 0.96 & 1.27 \\
\hline 2 & $\begin{array}{l}\text { Waste service delivery must be } \\
\text { adequate. That is, waste must } \\
\text { be disposed regularly }\end{array}$ & 174 & 4.67 & 0.59 & 220 & 4.64 & 0.57 & 0.51 \\
\hline 3 & $\begin{array}{l}\text { There must be fair and safe } \\
\text { working conditions and job } \\
\text { training for waste service } \\
\text { providers. }\end{array}$ & 174 & 4.31 & 0.78 & 220 & 4.20 & 0.85 & 1.35 \\
\hline 4 & $\begin{array}{l}\text { Waste collectors must have } \\
\text { technical resources (such as } \\
\text { equipment, expertise and skills) } \\
\text { to cope with waste } \\
\text { management }\end{array}$ & 174 & 4.47 & 0.68 & 220 & 4.35 & 0.80 & 1.58 \\
\hline 5 & $\begin{array}{l}\text { There must be management } \\
\text { flexibility. That is, ease in } \\
\text { firing waste personnel for non- } \\
\text { performance and in providing } \\
\text { upward mobility for workers } \\
\text { with good performance. }\end{array}$ & 174 & 3.84 & 0.90 & 220 & 3.73 & 1.04 & 1.12 \\
\hline 6 & $\begin{array}{l}\text { There must be a 'task' system } \\
\text { of work in which workers may } \\
\text { leave whenever they finish } \\
\text { their assigned route. }\end{array}$ & 174 & 3.68 & 0.85 & 220 & 3.61 & 0.98 & 0.76 \\
\hline 7 & $\begin{array}{l}\text { There must be a structure to } \\
\text { monitor the performance of } \\
\text { waste service providers. }\end{array}$ & 174 & 4.40 & 0.81 & 220 & 4.27 & 0.85 & 1.54 \\
\hline 8 & $\begin{array}{l}\text { The will to enforce or maintain } \\
\text { contractual agreements with } \\
\text { their clients must be present. }\end{array}$ & 174 & 3.90 & 1.07 & 220 & 3.65 & 1.09 & 2.28 \\
\hline
\end{tabular}

Source: Fieldwork by author

All items not significant at $\alpha=0.02$ in a two tailed test. In other words, the opinions of cart pushers' patrons and those of the PSP patrons tallies on what efficient and effective waste management should be. The scenario was however different with the commercial waste service clients who believed that efficiency in waste management entails all but the practicing of a task system. See details of result and ranking below. 
Table 2: Commercial clients' opinion of effective and efficient waste management

\begin{tabular}{|l|l|l|l|l|}
\hline 1 & $\begin{array}{l}\text { Commensurate service charges with level of solid waste } \\
\text { disposal. In other words, waste service delivery must not be } \\
\text { too costly. }\end{array}$ & $\begin{array}{l}\text { Observati } \\
\text { ons }\end{array}$ & $\begin{array}{l}\text { Mean } \\
\text { scores }\end{array}$ & $\begin{array}{l}\text { STD. } \\
\text { DEV. }\end{array}$ \\
\cline { 2 - 4 } 2 & $\begin{array}{l}\text { Waste service delivery must be adequate. That is, waste must } \\
\text { be disposed regularly }\end{array}$ & 32 & 4.69 & 0.54 \\
\hline 3 & $\begin{array}{l}\text { There must be fair and safe working conditions and job } \\
\text { training for waste service providers. }\end{array}$ & 32 & 4.69 & 0.25 \\
\hline 4 & $\begin{array}{l}\text { Waste collectors must have technical resources (such as } \\
\text { equipment, expertise and skills) to cope with waste } \\
\text { management }\end{array}$ & 32 & 4.63 & 0.47 \\
\hline 5 & $\begin{array}{l}\text { There must be management flexibility. That is, ease in firing } \\
\text { waste personnel for non-performance and in providing } \\
\text { upward mobility for workers with good performance. }\end{array}$ & 32 & 4.03 & 0.69 \\
\hline 6 & $\begin{array}{l}\text { There must be a 'task' system of work in which workers may } \\
\text { leave whenever they finish their assigned route. }\end{array}$ & 32 & 3.75 & 1.02 \\
\hline 7 & $\begin{array}{l}\text { There must be a structure to monitor the performance of } \\
\text { waste service providers. }\end{array}$ & 32 & 4.56 & 0.5 \\
\hline 8 & $\begin{array}{l}\text { The will to enforce or maintain contractual agreements with } \\
\text { their clients must be present. }\end{array}$ & 32 & 4.75 & 0.56 \\
\hline
\end{tabular}

Source: Fieldwork by the authors

Table two above shows corporate responses to the eight questions efficiency and effectiveness questions. The mean responses range between 3.73 and 4.94 which are quite high for acceptance apart from the mean score of 3.75 corresponding to the question of; There must be a 'task' system of work in which workers may leave whenever they finish their assigned route. Another observation about the responses is that they are all clustered around their mean values hence the standard deviations are low and ranges between 0.25 and 1.02 indicating that they all responded in agreement with the mean values. The above finding is in agreement with the submission of Daset al. (2008) andCointreanLevin (1994).

Table 3: Efficient and effective waste services' provision ranking

\begin{tabular}{|l|l|l|l|l|}
\hline 1 & $\begin{array}{l}\text { Commensurate service charges with level of solid waste } \\
\text { disposal. In other words, waste service delivery must not be } \\
\text { too costly. }\end{array}$ & $\begin{array}{l}\text { Mean } \\
\text { (Commercial) }\end{array}$ & $\begin{array}{l}\text { Mean scores } \\
\text { (PSP) }\end{array}$ & $\begin{array}{l}\text { Mean } \\
\text { (Cartpusher) }\end{array}$ \\
\cline { 2 - 5 } & $\begin{array}{l}\text { scores } \\
\text { Waste service delivery must be adequate. That is, waste must } \\
\text { be disposed regularly }\end{array}$ & 2.78 & 3.76 & 3.71 \\
\hline 3 & $\begin{array}{l}\text { There must be fair and safe working conditions and job } \\
\text { training for waste service providers. }\end{array}$ & 2.59 & 3.38 & 3.75 \\
\hline 4 & $\begin{array}{l}\text { Waste collectors must have technical resources (such as } \\
\text { equipment, expertise and skills) to cope with waste } \\
\text { management }\end{array}$ & 3.4 & 2.97 \\
\hline 5 & $\begin{array}{l}\text { There must be management flexibility. That is, ease in firing } \\
\text { waste personnel for non-performance and in providing } \\
\text { upward mobility for workers with good performance. }\end{array}$ & 2.74 & NA & NA \\
\hline 6 & $\begin{array}{l}\text { There must be a 'task' system of work in which workers may } \\
\text { leave whenever they finish their assigned route. }\end{array}$ & NA & 3.46 & NA \\
\hline 7 & $\begin{array}{l}\text { There must be a structure to monitor the performance of } \\
\text { waste service providers. }\end{array}$ & 2.74 & NA & NA \\
\hline 8 & $\begin{array}{l}\text { The will to enforce or maintain contractual agreements with } \\
\text { their clients must be present. }\end{array}$ & 2.78 & 3.55 & 3.37 \\
\hline & AVERAGE OF TOTAL & 2.8 & & \\
\hline
\end{tabular}

Source: Fieldwork by authors

The above table (table 3) presents also the mean responses of the three groups of patrons of each waste service (household patronizing the private sector participants and household patronizing the cartpushers and; firms and corporate bodies as patrons of commercial waste services or LAWMA). A deep look at the results indicates that all the service providers performed abysmally low. For instance, the mean score for commercial service providers (LAWMA) ranges between 2.59 and 3.22 for all the eight items. The rankings of the patrons of the private sector participants indicate a mean mark ranging from 3.36 to 3.76 with a total mean score of 3.55 . The mean scores of the cartpushers' patrons ranges from 2.97 to 3.75 and a grand mean of 3.37 . 
The PSP ratings is highest based on the general ratings above followed by the cartpushers and the commercial service providers or LAWMA came last. Although the PSP ranking is the highest, none of the service providers did well enough to be classified as delivering efficient and effective solid waste management suggesting that there is much to be done. The above finding is similar to the submissions by Choi (2016) and Orhorhoro and Oghoghorie (2019).

\subsection{Conclusions}

Inefficiency and ineffectivenessin municipal solid waste management system has the potential of damaging the ecosystem services, contaminate ground and surface water, creates greenhouse gas emissions, increase disease transmission, damages ecosystem services and discourages tourism and other businesses (Fenta, 2017). To this end, this study conducted a study on the efficiency and effectiveness of solid waste services in Lagos state using primary data and conducting statistical tests. The study found a general agreement on what constitutes efficient and effective solid waste services. However, the study concluded that waste management system in Lagos State is inefficient, ineffective and therefore unsustainable. The study therefore recommends that there is an urgent need to reorganize the waste management institutions for effective and efficient performance. Although the collection and disposal of refuse can be done with little knowledge and limited equipment, effective and efficient waste management requires substantial planning ability, appropriate equipment and continuous managerial optimization of vehicles and workers productivity. The above stated ingredients are the technology for efficient waste management. Waste management Agencies must ensure that PSPs to be licensed must have the appropriate technology capable of ensuring its success in this field.

Smaller younger crews, lower absenteeism, wages and benefit cost, more flexible scheduling, efficient vehicle routing, better designed vehicles, managerial incentives, faster vehicle repairs, vehicle standardization, and competition are parts of the requirements for qualification for appointment as a PSP operator. Also to be specified are: Well defined systems of collection in lowincome or squatter settlement areas since low income areas are often characterized by narrow or steeply graded roads that are often inaccessible even to smaller vehicles, so an integration of cartpushers (or the informal sector) by a PSP should be his sole discretion including their control. PSP should also be allowed to have and operate transfer stations within their domain.

In addition, to ensuring public education, inspection, auditing and enforcement of laws regulating citizens' behaviour, Waste Management Agency must ensure that each franchisee provides or make adequate provision for collection service to all residents wherever they are within their domain. This will ensure that citizens do not litter indiscriminately. This is so important in view of the fact that the cost of cleansing up can be very high. Based on the findings of Cointrean-Levine (1994), the costs per tonne of public cleansing (including general clean-up of open areas and street sweeping) are two to three times the costs per tonne of collection. So far, much progress has been made in reducing dumping, but much more needs to be done in regulatory reform, economic policy reform, and environmental management within Lagos State. The key focus of these reforms must be transparency of waste management agencies so that individuals can be sure of equity and fairness. Transparency is important as it prevents corruption and ensures ready access of communities to information. Proper coordination of waste management sectors to avoid conflicts and loopholes, as well as community participation. Privatizing some aspects of solid waste service delivery does not and should not in any way take away the need for Local Government, Ministry of Environment and LAWMA to be fully responsible for solid waste management service.

\section{Acknowledgement}

Special thanks: I acknowledge the contributions of late Prof.TayoFakiyesi for his invaluable contributions to this publication.

\section{References}

Adedayo (2000). Environmental sanitation and waste management policies at the local level in Nigeria. Geo-studies Forum, 1(1): pp. 29 - 37. 
Adedibu, A.A. (1985).A comparative analysis of solid waste composition and generation in two cities of a developing nation.The Environmentalist, 5(2),pp.123-127.

Adeogba, A. G. (2000).Applying technological determinism to MSW-disposal in Nigeria.Seminar document, October pp.1-11.

Alan, P. and Ahmade, K. (2013).Impact of solid waste on health and the environment.International Journal of Sustainable Development and Green Economics, 2(1),pp. 165 - 168.

Ayadi, F. S. (2008).Economics of wastes management in Lagos State, Nigeria (1980 2003).Unpublished doctoral dissertation, University of Lagos, Nigeria.

Barbereyie, A. (2009). Urban Environmental problems in Ghana: a case study of social and environmental injustice in solid waste management in Accra and SekondiTakoradi. Ph.Dthesis submitted to the school of Geography, University of Nottingham.

Boadi, K.O. and Kuitunem, M. (2005).Environment, wealth, inequality and the burden of disease in the Accra metropolitan area, Ghana.International Journal of Environmental Health Research, 15,pp. 193-206.

Boateng, S., Amoako, P., Appiah, D. O., Poku, A. A., and Garsonu, E. K. (2016). Comparative analysis of households solid waste management in rural and urban Ghana. Journal of Environmental and Public Health, ID 5780258. Retrieved from http://dx.doi.org/10.1155/2016/5780258

Choi, H.J. (2016). The environmental effectiveness of solid waste management a case study of Oslo Norway.Master Thesis in Culture, Environment and Sustainability. Centre for development and environment. University of Oslo.

Cointrean-Levine S. (1978 to 1992). Conversations with solid waste Managers from developing country local and central governments and with solid waste specialists and private refuse haulers from developing countries.

Cointrean-Levine, S. (1994).Private sector participation in municipal solid waste services in developing countries.Urban Management and Municipal Finance, World Bank, Washington D.C. pp.41.

Coyaud, D. P. (1988). Private and public alternatives for providing water supply and sewerage services.

Das, S., Birol, E. and Bhattacharya, R. N. (2008).Informing efficient and effective solid waste management to improve local environmental quality and public health: Application of the choice experiment method in West Bengal, India. University of Cambridge environmental economy and policy research discussion paper series number 33 .

Fei-Baffoe, B., Nyankson, E.A. and Gorkeh-Miah, J. (2014).Municipal solid waste management in Sekondi-Takoradi metropolis, Ghana.Journal of Waste Management, Article ID 823752.

Fenta, B. A. (2017). Waste management in the case of Dar City near Lake Tana shore in Northwestern Ethiopia: A review. African Journal of Environmental Science and Technology, 11(8),pp. 393 - 412.

Kütting, G. (2000).Environment, society and international relations: Towards more effective international environmental agreements. New York: Routledge.

Kütting, G. (2001). A critical approach to institutional and environmental effectiveness: lessons from the convention on long-range transboundary air pollution, pp.181-198 in The Political Economy of The Environment: Critical Perspectives, Edited by D. Stevis and Assetto, V. Lynne Rienner.

Colorado, the USA. 
LAWMA (2011). Waste management progress report for the month of November 2011. Retrieved from: www.lawma.gov.ng

LAWMA (2015).Domestic solid waste generation.

LAWMA (Undated).Landfill gate records.

Orhorhoro, E .k. and Oghoghorie, O. (2019). Review on solid waste generation and management in Sub-Saharan Africa: A case study of Nigeria. Journal of Applied Science and Environmental Management, 23(9), pp. 1729-1737.

World Bank (1991).World Development Report, 1991: The challenge of development. New York. Oxford University Press. Xii 
Appendix: An extract from the questionnaires of the study SECTION C

(1) Who collects your waste? LAWMA ( ); PSP operator ( ); Cart pushers ( ); self-disposal ( ); Others (please specify)

(2) Efficient and effective waste management entails:

\begin{tabular}{|c|c|c|c|c|c|}
\hline & $\begin{array}{l}\text { I strongly } \\
\text { agree }\end{array}$ & I agree & It depends & I disagree & $\begin{array}{l}\text { I strongly } \\
\text { disagree }\end{array}$ \\
\hline $\begin{array}{l}\text { (i) Commensurate service charges with level } \\
\text { of solid waste disposal. In other words, waste } \\
\text { service delivery must not be too costly. }\end{array}$ & $(\quad)$ & $(\quad)$ & $(\quad)$ & $(\quad)$ & $(\quad)$ \\
\hline $\begin{array}{l}\text { (ii) Waste service delivery must be adequate. } \\
\text { That is, waste must be disposed regularly. }\end{array}$ & $(\quad)$ & () & $(\quad)$ & () & () \\
\hline $\begin{array}{l}\text { (iii) There must be fair and safe working } \\
\text { conditions and job training for waste service } \\
\text { providers. }\end{array}$ & $(\quad)$ & $(\quad)$ & ( ) & $(\quad)$ & ( ) \\
\hline $\begin{array}{l}\text { (iv) Waste collectors must have technical } \\
\text { resources (such as equipment, expertise and } \\
\text { skills) to cope with waste management. }\end{array}$ & $(\quad)$ & ( ) & $(\quad)$ & $(\quad)$ & $(\quad)$ \\
\hline $\begin{array}{l}\text { (v) There must be management flexibility. } \\
\text { That is, ease in firing waste personnel for } \\
\text { non-performance and in providing upward } \\
\text { mobility for workers with good performance. }\end{array}$ & ( ) & ( ) & $(\quad)$ & $(\quad)$ & ( ) \\
\hline $\begin{array}{l}\text { (vi) There must be a 'task' system of work in } \\
\text { which workers may leave whenever they } \\
\text { finish their assigned route. }\end{array}$ & $(\quad)$ & ( ) & ( ) & ( ) & ( ) \\
\hline $\begin{array}{l}\text { (vii) There must be a structure to monitor the } \\
\text { performance of waste service providers. }\end{array}$ & $(\quad)$ & $(\quad)$ & ( & $(\quad)$ & $(\quad)$ \\
\hline $\begin{array}{l}\text { (viii) The will to enforce or maintain } \\
\text { contractual agreements with their clients } \\
\text { must be present. }\end{array}$ & $(\quad)$ & ( ) & ( ) & $(\quad)$ & ( ) \\
\hline
\end{tabular}

(3) How would you rank your waste service provider (for example, LAWMA, PSP operator, cart pusher etc.) in relation to the following?

\begin{tabular}{|c|c|c|c|c|c|}
\hline & Excellent & Good & Fair & Poor & $\begin{array}{l}\text { Very } \\
\text { Poor }\end{array}$ \\
\hline service delivery is not too costly. & $(\quad)$ & $(\quad)$ & $(\quad)$ & $(\quad)$ & $(\quad)$ \\
\hline $\begin{array}{l}\text { (ii) Waste service delivery's adequacy. That is, } \\
\text { waste is disposed regularly. }\end{array}$ & $(\quad)$ & $(\quad)$ & $(\quad)$ & $(\quad)$ & () \\
\hline $\begin{array}{l}\text { (iii) Fair and safe working conditions and job } \\
\text { training for waste service providers. }\end{array}$ & $(\quad)$ & $(\quad)$ & $(\quad)$ & $(\quad)$ & $(\quad)$ \\
\hline $\begin{array}{l}\text { (iv) Waste collectors' technical resources } \\
\text { (such as equipment, expertise and skills) to } \\
\text { cope with waste management. }\end{array}$ & ( ) & ( ) & ( ) & $(\quad)$ & $(\quad)$ \\
\hline $\begin{array}{l}\text { (v) Management flexibility. That is, ease in } \\
\text { firing waste personnel for non-performance } \\
\text { and in providing upward mobility for workers } \\
\text { with good performance. }\end{array}$ & ( ) & ( ) & & $($ ) & $(\quad)$ \\
\hline $\begin{array}{l}\text { (vi) Practising of a 'task' system of work in } \\
\text { which workers may leave whenever they finish } \\
\text { their assigned route. }\end{array}$ & ( ) & ( ) & & ( ) & $(\quad)$ \\
\hline $\begin{array}{l}\text { (vii) The availability of an effective structure } \\
\text { to monitor the performance of waste service } \\
\text { providers. }\end{array}$ & ( ) & ( ) & ( ) & $(\quad)$ & $(\quad)$ \\
\hline $\begin{array}{l}\text { (viii) The will to enforce or maintain } \\
\text { contractual agreements with their clients. }\end{array}$ & $(\quad)$ & $(\quad)$ & $(\quad)$ & $(\quad)$ & $(\quad)$ \\
\hline
\end{tabular}

(4) What percentage is waste in the running cost of your company? $0 \%-5 \%$ ( );6\%-10\% ( ); 11\%-15\% ( );16\%-20\% ( ): $21 \%-25 \%$ ( ).

\section{Cite this article as:}

Ayadi, F. S. and Alo, B. I., 2020.Effectiveness and Efficiency Solid Waste Services in Lagos State, Nigeria.Nigerian Journal of Environmental Sciences and Technology, 4(2), pp. 272-282. https://doi.org/10.36263/nijest.2020.02.0214 